\title{
The Perception of the Patient on the Unit of Intensive Therapy: Literature Review
}

\author{
Nepomuceno Júnior BRV ${ }^{1 *}$ and Silva da Silva LF ${ }^{2}$ \\ ${ }^{1}$ Master in Medicine and Health from the Federal University of Bahia, Responsible Technical Rehabilitation Specialized Physiotherapy, Brazil
}

${ }^{2}$ Physiotherapist, Specialist in Hospital Physiotherapy by the Bahiana School of Medicine and Public Health, Brazil

Submission: January 17, 2018; Published: August 23, 2018

*Corresponding author: Balbino Rivail V Nepomuceno Junior, Master in Medicine and Health from the Federal University of Bahia, Responsible Technical Rehabilitation Specialized Physiotherapy, Av. Centenário, Ed. Empresarial Centenario, Chame-chame, Salvador-Bahia, Brazil; Email: balbino.nepomuceno@gmail.com

Abstract

Introduction: Although the recognition that the ICU is one of the major responsible for the evolution in health care in the last century, society continues with a stereotyped view, considering it as an aggressive, invasive, tense and traumatizing environment.

Objective: To review the literature to compare the perception of ICU patients about this environment and the professionals who work there.

Methods: A search was made in the scientific literature through queries in the electronic databases Lilacs, Medline, Pubmed and Scielo, from the descriptors: perception, patients and intensive care unit and their correlates in English. We included original scientific studies of descriptive, experimental or causal - comparative typology; published between 1995-2015; dependent variable perception of patients on the ICU; patients who have been hospitalized; samples composed of individuals older than 18 years and preserved cognitive ability; clarity in the samples and analyzes.

Results: A total of 63 articles were found, of which 50 were excluded because they did not meet the inclusion criteria. Eight articles were used for analysis and discussion, being grouped in tables.

Conclusion: This literature review concludes that the ICU presents several stressors, both sensory factors and emotional factors provoked by the experiences and uncertainty of the outcome in the face of disease. The role of the interdisciplinary team is a fundamental point to address the resolution of these stressors.

Keywords: Perception; Patients; Intensive care unit; Articles; Stereotyped view; Comparative typology; Traumatizing environment; Intensive Care Unit

Abbreviations: ICU: Intensive Care Unit; DeCS: Health Sciences Descriptors; MeSH: Medical Subject Headings

\section{Introduction}

The Intensive Care Unit (ICU) is a site dedicated to the care of critically ill patients with clinical instability. Its approach is interdisciplinary and characterized by frequent use of diverse technological equipment, aiming at continuous monitoring and advanced support of life [1-6].

From its conception in the mid-nineteenth century during the Crimean War, Florence Nightingale realized the need to isolate the most serious patients and established continuous surveillance [7-11]. In this context, the ICU acquired the image before society of a segregating and inhospitable place, directly associated with death, pain and despair [8].

Although the recognition that the ICU is one of the major responsible for the evolution in health care and reduction of hospital mortality rates in the last century, society continues with a stereotyped view, considering it as an aggressive, invasive, tense and traumatizing environment. In addition, although the patient shares the same space with other patients and with health professionals, the fact of being sometimes decharacterized and depersonalized, displaced from their familiar, social and professional environment to an unknown environment, generates in this patient feelings ambiguous of anxiety, isolation and lack of privacy [4,5,8-14].

Even today, the number of studies that raise the patient's impression about this environment, as well as the psychological and social impacts of ICU admission is limited. The data present in the literature presents with different methodologies and visions, and it is necessary to compile this information in order to have a more linear impression of the patients' perception about this care unit. Only then, adjustments and improvements can be made in this environment and in the professionals working in this unit to better accommodate patients. In this context, the purpose of this article is to review the literature to compare the perception of ICU patients about this environment and the professionals who work there. 


\section{Methods}

This is a review of the literature, addressing the perception about ICU by the patients hospitalized in this unit.

\section{Inclusion criteria}

Included were: original scientific studies; classified in their typology as descriptive, experimental or causal -comparative; published between 1995-2015; considering as an independent variable the patients' perception about the ICU; including in its sample patients who were hospitalized; being composed by individuals over 18 years of age and with preserved cognitive capacity. Articles with languages other than English, Portuguese and Spanish were excluded, as well as a study that expressed the opinion of third parties about the ICU environment.

\section{Search strategy}

Initially the descriptors were established: perception; patient; intensive care unit. As well as their English-language correspondents and their synonyms, available in the Health Sciences Descriptors (DeCS) and Medical Subject Headings (MeSH). In order to maximize the search were adapted related words used in pre-retrieved scientific articles.

Respecting the operational differences of each database, when possible, it was decided to search the "Title" or "Keyword" primary fields using Boolean operators "or" and "and" and "connectors" and the term "patient" as the limit. The research was carried out in the following databases: LILACS, MEDLINE,
SciELO, PudMed. The literature review was carried out from January to June 2016.

\section{Selection criteria}

The articles identified by the search strategy were independently and blindly evaluated by two researchers LFSS and BRVNJ, strictly adhering to the inclusion criteria. The selection of the articles was initiated by the use of the keywords; followed by the selection of articles by the titles, which privileged the patient's perception about the ICU; in the next phase the pre-selected articles had the summaries read, including studies that fit the inclusion criteria described above. Finally, due to the cut-off point established for the selection criteria, a more experienced researcher analyzed the article in case the two researchers had a divergence in the decision about including the study in the systematic review.

\section{Presentation of data}

To better understand the data, the articles and their results were grouped in their own table, containing: author and year of publication; study design; sample size and outcomes. Approaching in this table main quantitative as well as qualitative results on the independent variable in question.

\section{Result}

We found 63 articles, of which 50 were excluded because they did not meet the inclusion criteria. This article includes 13 articles (Figure 1).

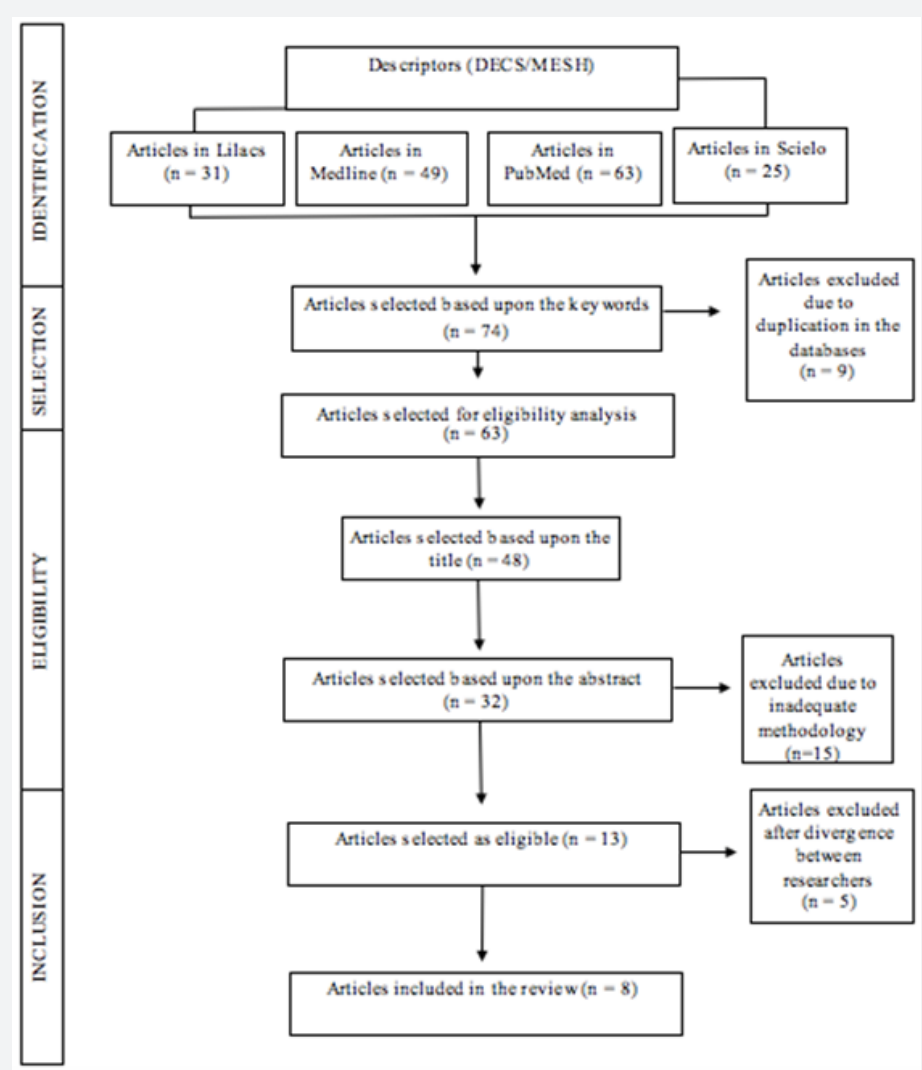

Figure 1: Flowchart for selection of articles in the review. 
Table 1: Perception of patients admitted to the ICU.

\begin{tabular}{|c|c|c|c|}
\hline $\begin{array}{l}\text { Author, Year of } \\
\text { Publication }\end{array}$ & Method & Sample & Despite \\
\hline Guirardello EB et al. [9] & $\begin{array}{l}\text { Qualitative study, semi-structured } \\
\text { interview. }\end{array}$ & 10 & $\begin{array}{l}\text { The patient has a stereotyped view of the ICU, linked to the } \\
\text { idea of suffering, death and finitude; fragility, physical and } \\
\text { emotional dependence. Another important aspect, in the } \\
\text { testimony, was the restricted notion about timing, arising from } \\
\text { the ICU environment and the degree of physical dependence. In } \\
\text { contrast, the testimonies also brought aspects aimed at being } \\
\text { reborn. }\end{array}$ \\
\hline $\begin{array}{l}\text { Severo GC and Girardon- } \\
\quad \text { Perlin NMO [13] }\end{array}$ & $\begin{array}{l}\text { Qualitative descriptive study, } \\
\text { questionnaire. }\end{array}$ & 8 & $\begin{array}{c}\text { The ICU was considered a strange and mysterious environment, } \\
\text { unknown and unfriendly, associated with death and serious } \\
\text { illness, recovery and reunion with life, and as a place of } \\
\text { suffering. }\end{array}$ \\
\hline $\begin{array}{l}\text { Moreira ML and Castro ME } \\
\qquad[12]\end{array}$ & Descriptive study, interview. & 8 & $\begin{array}{l}\text { The patients perceived the ICU as a place destined to receive } \\
\text { serious patients, with risk of death and with possibilities of } \\
\text { recovery. The technology and the multiprofessional team's } \\
\text { efforts to reverse the patient's critical situation make the ICU } \\
\text { environment inhuman and exhausting for patients. Stress } \\
\text { factors include light, noise, sleep deprivation, insecurity, shame } \\
\text { and longing. }\end{array}$ \\
\hline Cesarino CB et al. [5] & $\begin{array}{l}\text { Descriptive qualitative study, } \\
\text { semistructured interview. }\end{array}$ & 50 & $\begin{array}{l}\text { This study reported a positive view of the vast majority of } \\
\text { the participating patients, in which } 42(84 \%) \text { related such } \\
\text { environment to life-saving treatment. Only } 8(16 \%) \text { perceived } \\
\text { the ICU negatively, as a site related to fear, loss of autonomy } \\
\text { and anguish with the outcome. }\end{array}$ \\
\hline Faquinello P and Dióz M [7] & Qualitative study, open interview. & 10 & $\begin{array}{l}\text { The ICU was considered a place where the interpersonal } \\
\text { relationship is difficult; distress, loss of privacy and exposure } \\
\text { of the patient to professionals and other patients. Aggressive } \\
\text { and traumatic, by the noises, absence of the family, dissociation } \\
\text { with the external environment, dependence on other people to } \\
\text { realize basic needs and the lack of individualized attention. }\end{array}$ \\
\hline Pina RZ et al. [4] & $\begin{array}{l}\text { Descriptive qualitative study, open } \\
\text { interview }\end{array}$ & 11 & $\begin{array}{l}\text { It was reported by most patients the perception of an } \\
\text { environment of loneliness and homesickness, embarrassment } \\
\text { of body exposure, difficulty sleeping at night, given noises } 24 \\
\text { hours, lack of autonomy, sometimes exposed with contention } \\
\text { extremities in the bed. A minority of the sample was able } \\
\text { to perceive the ICU as an enabling environment for life and } \\
\text { healing. }\end{array}$ \\
\hline $\begin{array}{l}\text { Proenca MO and Agnolo } \\
\text { CMD [3] }\end{array}$ & $\begin{array}{l}\text { Qualitative descriptive- } \\
\text { exploratory study, open interview. }\end{array}$ & 10 & $\begin{array}{l}\text { It showed two moments of perception, initially, the majority of } \\
\text { the sample related to the ICU with terminality and suffering, } \\
\text { with perception of a second moment of overcoming and } \\
\text { recovery in the face of illness and debilitation. }\end{array}$ \\
\hline $\begin{array}{l}\text { Pupulim JSL and Sawada } \\
\text { NO [11] }\end{array}$ & $\begin{array}{l}\text { Descriptive study, open } \\
\text { questionnaire. }\end{array}$ & 34 & $\begin{array}{l}\text { Patients reported discomfort and embarrassment at nudity and } \\
\text { body touch during routine procedures. }\end{array}$ \\
\hline
\end{tabular}

Table 1 expresses the patients' perception of hospital admission of the eight articles included in the study. Of these, $6(75 \%)$ of the studies revealed a negative perception generally aggravated by the structuring of the architectural environment, however aggravated by the positioning of the professionals acting there in the face of the suffering and the need of these patients.
Two studies extolled the therapeutic potential of the environment, compared to other environmental stressors. The most perceived negative factors in the ICU were loss of autonomy and loss of privacy, reported in 5 of the 8 articles included in this review, followed by death, which was reported in 4 articles (Table 2). 
Table 2: Factors listed with ICU present, in the perception of patients who have undergone intensive care hospitalization.

\begin{tabular}{|c|c|c|c|c|c|c|c|c|}
\hline Factors & $\begin{array}{c}\text { Guirardello } \\
\text { EB et } \\
\text { al.,1999. [9] }\end{array}$ & $\begin{array}{c}\text { Severo } \\
\text { GC and } \\
\text { Girardon - } \\
\text { Perlin NMO, } \\
\text { 2005. [13] }\end{array}$ & $\begin{array}{l}\text { Moreira ML } \\
\text { and Castro } \\
\text { ME, 2006. [2] }\end{array}$ & $\begin{array}{l}\text { Cesarino } \\
\text { CB et al., } \\
\text { 2006. [5] }\end{array}$ & $\begin{array}{c}\text { Faquinello } \\
\text { P and Dióz } \\
\text { M, 2007. } \\
\text { [7] }\end{array}$ & $\begin{array}{l}\text { Pina RZ et } \\
\text { al., 2008. [4] }\end{array}$ & $\begin{array}{c}\text { Proenca MO } \\
\text { and Agnolo } \\
\text { CMD, 2011. } \\
\text { [3] }\end{array}$ & $\begin{array}{c}\text { Pupulim JSL } \\
\text { and Sawada } \\
\text { NO, 2010. } \\
\text { [11] }\end{array}$ \\
\hline \multicolumn{9}{|l|}{ Negatives } \\
\hline Death & + & + & + & & & & + & \\
\hline Fear & + & & & + & & & & \\
\hline Dehumanization & & + & & & + & + & & \\
\hline Anguish & & & & + & + & & & + \\
\hline Stress & & + & + & & & & & \\
\hline Loss of Autonomy & + & & & + & + & + & & + \\
\hline Privacy Loss & + & & + & & + & + & & + \\
\hline Suffering & + & + & & & & & + & \\
\hline Sleep deprivation & & & + & & & + & & \\
\hline Noise & & & + & & + & + & & \\
\hline Family Spacing & & & + & & + & + & & \\
\hline $\begin{array}{c}\text { Communication } \\
\text { impairment }\end{array}$ & & & & & + & & & \\
\hline \multicolumn{9}{|l|}{ Positives } \\
\hline Cure & & & & + & & + & & \\
\hline Recovery & & + & + & + & & & + & \\
\hline Restarting Life & + & + & & + & & & + & \\
\hline
\end{tabular}

\section{Discussion}

From the present literature review one can perceive the ambiguity in the patient's perception about the intensive care setting. It is noted that a set of intrinsic and extrinsic factors converge to a positive or negative perception of this environment.

An ICU concentrates the human and material resources necessary for the adequate care of patients, whose clinical status requires constant, specialized and uninterrupted health care. It is considered an environment hostile to human nature because it enhances physical fragility and emotional vulnerability to the health-disease process. In confronting the disease and treatment, patients are faced with circumstances that interfere with their lifestyle, in addition to living with people who are not part of their social structure $[8,13]$.

The main objective of an Intensive Care Unit is to restore in severe patients the functioning of one or more severely altered organ systems until the underlying disease is adequately compensated or until the physiological parameters reach acceptable levels. In order to do so, the technological advance in this sector aims to integrate the technology to the care, dominating the scientific principles that base its use and at the same time supplying the therapeutic needs of the patients and preserving their individuality $[8,15]$. In this context, the urgency and the invasiveness of the procedures performed are almost always perceived to patients by feelings such as hostility, coldness and impersonality, making it necessary to reflect on the real role of the human resource allocated in the ICU, if the must it be purely technical excellence, or does it require more and more sensitivity in transferring to the feelings of others, always respecting the professional callosity that will make the execution of their office possible?

Among the characteristics of this type of unit, it includes the intensive care, patients that present risk of death, in addition to the physical structure composed of several equipment and human resources. These characteristics associated with the stereotypes brought by the patients and the coexistence with other people in serious condition, make the perception of the own death as a concrete possibility [14]. Several authors point out that patients perceive the Intensive Care Unit as an environment related to death [5-8, 10,12,15,16]. In the reports collected in a hospital in the southwest of São Paulo, Brazil, the fear of dying is intimately related to the lack of knowledge and uncertainty of what is happening in this environment and that previous experience with the suffering of some known in the Unit contributes to accentuate this feeling [6].

Likewise, in the studies conducted in a coronary unit in São José do Rio Preto/SP [8] and the Federal University of Maringá [7], the fear of dying was a symptom reported by some of the interviewees $[7,8]$. The very term "intensive therapy" already causes an emotional overload, associating this environment with the finitude of life [8]. It was also reported by Severo GC and Girardon-Perlini NMO (2005) that fear of death is considered as part of the dying process and therefore many of the participants 
avoided speaking the word "death", evidencing the denial of this process and the difficulty of the patients to deal with the finitude of life [16].

In ICUs patients usually stay together, in the same physical space or with partitions that make it possible to see, hear and perceive everything that happens around them [16] and begin to develop considerable sensitivity to what is happening around them, given the stress situation faced in the ICU [10]. In contrast, stressors, almost existential in the routine of the ICU, such as fear, death and pain, it is well known that the team's attitude towards such concerns is decisive in the way in which these feelings will be perceived and they will influence or not the structural and functional recovery of organic and psychic systems.

The use of equipment, probes, drains and catheters makes the patient feel uncomfortable, but considers them important for their recovery [16]. On the other hand, routine activities in the ICU are stress-generating factors and placed as extremely negative because they result in a noisy, inhospitable and highly stressful environment [10]. The strange machinery, constant deprivation, sleep interruptions, sensory overstimulation, thirst, pain, nasal feeding, ventilator breathing, continuous monitoring and signs, catheters, invasive procedures, artificial lighting, conversations, and lack of privacy trigger the patient's sense of anguish, making them perceive the environment as unfriendly $[5,6,10]$.

Corroborating the above, this feeling of anguish was cited by patients in several studies as a negative factor in their stay in the ICU $[5-8,10,12,15,16]$. The difficulty of understanding the intensive physical environment caused by sedation or organic weakness are factors that intensify this perception and show the stigma attributed to this sector [10]. In the study conducted by Moreira e Castro (2006), the interviewees considered that the technology and the multiprofessional team acting in the eagerness to reverse the patient's critical situation make the ICU environment inhumane and exhausting [15].

Still regarding the feeling of anguish experienced by the patients, the interviewees in a university hospital in CampinasSP explained about the prison feeling for the equipment, loss of the notion of time, lack of natural light and alteration of the sleep-wake cycle, and exclusion from discussions about their treatment [12].

The illness condition also generates feelings such as incapacity, dependence, insecurity and loss of control over oneself that make hospitalized patients consider hospitalization a factor of depersonalization because they recognize the difficulty in preserving their identity, individuality and privacy [7].

The perception of deprivation of autonomy, of freedom, lack of mastery of the situation coupled with physical weakness, and dependence, leads to a state of inactivity and arises for the patient as part of a reality that is difficult to accept mainly in the acute phase of the disease [5]. In this context, Faquinello and Dióz emphasize that the principle of autonomy must be considered, guiding the actions of professionals working in this area [10].

Associated with deprivation of independence, the hospitalized patient feels more needy, fragile, insecure and lonely. Although they are in the company of the health team and other inmates, respondents in several studies felt that being away from family members, their home and their routine, made them feel alone and unprotected $[5,7,16]$. In this sense, Severo and Girardon-Perlini understand that the presence of a relative is emotional security for the hospitalized patient, besides being a preventive measure to the problems related to the psychosocial integrity of the patient [16]. The lack of privacy, especially at bath time, was another point addressed in the articles studied [8,14]. Pupulim \& Sawada [14], emphasize that in health care the violation of a person's privacy can occur in varied forms and at different levels, such as information, personal and territorial space, body, psychological and moral field.

An important and unavoidable complaint cited in the study by Guirardello et al. [12] is pain, caused by several factors, such as them, procedures and, often, physical discomfort itself. However, pain is difficult to analyze because it has a subjective, individual and emotional character, that is, it has a direct relationship with what each person is, feels and experiences $[12,15]$.

Although many studies show that the common understanding about the ICU characterizes it as an impersonal and inhumane environment, destined to patients on the verge of death, besides connoting to the professionals there acting, coldness and insensitivity, the articles analyzed showed that, after the period of hospitalization, the patients began to relate the ICU with recovery, overcoming and synonymous with life. In addition, they perceive and recognize the dedication, the continuous care and in a complete way, the humanization of the care provided by the health team $[6-8,10,12-15]$.

It is observed that when the patient identifies the team as a source of safety, protection and care, he begins to establish a relationship of trust with the professionals and to make sure that he is being cared for. Thus, even distant from the family, the patient feels supported and assisted, contributing to a positive image and satisfactory perception about the period of hospitalization $[7,16]$.

At present, several studies address the need to adopt a humanized posture by the interdisciplinary team, such postures come from structural adjustments in the unit, such as placement of windows, televisions and clocks near the patient's bed, until a hearing of the demands and complaints experienced by the patient and family, as well as more complex measures such as immersion of family members 24 hours in the unit or programs of continuing education in waiting room and patient care in groups or in external environments the unit or idealized to host or include this patient [17-20]. 
The experience of hospitalization and the disease itself put the human being in a crisis situation. It is fundamental that the intervention in the ICU preserves both the physiological and the mental health of the patient, helping in its full recovery through a humanized care and allowing it to perceive the experience in the ICU in the best possible way. Further studies are needed to evaluate the impact of adaptive measures to reduce negative experiences during hospitalization and to address the importance of physiotherapy in this context.

\section{Conclusion}

The present review concludes that the ICU presents several stressors, be they sensory factors such as noise, lightness and invasive procedures that bring pain, as well as emotional factors provoked by the experiences and uncertainty of the outcome in the face of disease.

The role of the interdisciplinary team seems to be the fundamental point to delineate if the patient exposed to these stressors will understand such experience with an example of overcoming and new life opportunity or as a traumatic experience that mostly leaves physical and psychic.

\section{References}

1. Nepomuceno Júnior BRV, Martinez BP, Gomes NM (2014) Impact of hospitalization in an intensive care unit on range of motion of critically ill patients: a pilot study. Rev Bras Ter Intensiva 26(1): 65-70.

2. Herridge MS, Tansey CM, Matté A, Tomlinson G, Diaz-Granados N, et al. (2005) Functional disability 5 years after acute respiratory distress syndrome. N Engl J Med 364(14): 1293-1304.

3. Nepomuceno Junior, BRV, Barreto SM, Almeida NC, Guerreiro CF, et al. (2017) Safety and efficacy of inspiratory muscle training for preventing adverse outcomes in patients at risk of prolonged hospitalisation. Trials 18(1): 626.

4. Pereira Júnior GA, Francisco Antônio Coletto, Martins MA, Flávio Marson, Lovato Pagnano RC, et al. (1999) 0 papel da unidade de terapia intensiva no manejo do trauma. Medicina, Ribeirão Preto 32: 419-437.

5. Backes DS, Lunardi Filho WD, Lunardi VL (2005) Humanização hospitalar: percepção dos pacientes. Acta Sci. Health Sci 27(2): 103107.

6. Proenca MO, Agnolo CMD (2011) Internação em unidade de terapia intensiva: percepção de pacientes. Rev. Gaúcha Enferm. (Online) 32(2): 279-286.

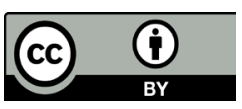

This work is licensed under Creative

Commons Attribution 4.0 License

DOI: 10.19080/JCMAH.2018.07.555709
7. Pina RZ, Lapchinsk LF, Pupulim JSL (2008) Percepção de pacientes sobre o período de internação em unidade de terapia intensive. Ciênc. cuid. Saúde 7(4):503-508.

8. Cesarino CB, Rodrigues AMS, Mendonça RCHR, Corrêa LCL, Amorim RC (2005) Percepções dos pacientes em relação à Unidade Terapia Intensiva. Arq Ciênc Saúde 12(3): 158-161.

9. Lopes FM, Brito ES (2009) Humanização da assistência de fisioterapia: estudo com pacientes no período pós-internação em unidade de terapia intensiva. Rev Bras Ter Intensive 21(3): 283-291.

10. Faquinello P, Dióz M (2007) A UTI na ótica de pacientes. Rev Min Enf 11(1): 41-47.

11.Zambom LS (2014) Segurança do paciente em terapia intensiva: caracterização de eventos adversos em pacientes críticos, avaliação de sua relação com mortalidade e identificação de fatores de risco para sua ocorrência. Tese (doutorado) - Faculdade de Medicina da Universidade de São Paulo. São Paulo.

12.Guirardello EB, Romero-Gabriel CAA, Pereira IC, Miranda AF (1999) A percepção do paciente sobre sua permanência na Unidade de Terapia Intensiva. Rev Esc Enf. USP 33(2):123- 129.

13.Pupulim JSL, Sawada NO (2012) Percepção de pacientes sobre a privacidade no hospital. Rev Bras Enferm 65(4): 621-629.

14. Pupulim JSL, Sawada NO (2010) Privacidade física referente à exposição e manipulação corporal: percepção de pacientes hospitalizados. Texto \& Contexto - Enfermagem 19(1): 36-44.

15. Moreira ML, Castro ME (2006) Percepção dos pacientes em unidade de terapia intensica frente à internação. Rev RENE 7(1): 75-83.

16.Severo GC, Girardon-Perlin NMO (2005) Estar internado em unidade de terapia intensiva: percepção de pacientes. Scientia Medica 15(1): 21-29.

17.Caetano JA, Andrade LM, Soares E, Ponte RM (2007) Cuidado humanizado em Terapia Intensiva: Um estudo reflexivo. Esc Anna Nery R Enferm 11(2): 325-330.

18.Casate JC, Corrêa AK (2005) Humanização do atendimento em saúde: conhecimento veiculado na literatura brasileira de enfermagem. Rev Latino-am Enfermagem 2005 janeiro-fevereiro 13(1): 105-111.

19.Vila VSC, Rossi LA (2002) O significado cultural do cuidado humanizado em unidade de terapia intensiva: ìmuito falado e pouco vivido. Rev Latino- am Enfermagem 2002 marÁo-abril 10(2): 137-144.

20. Mota RA, Martins CGM, Véras RM (2006) Papel dos profissionais de saúde na política de humanização hospitalar. Psicologia em estudo 11(2): 323-330.

\section{Your next submission with Juniper Publishers will reach you the below assets}

- Quality Editorial service

- Swift Peer Review

- Reprints availability

- E-prints Service

- Manuscript Podcast for convenient understanding

- Global attainment for your research

- Manuscript accessibility in different formats

( Pdf, E-pub, Full Text, Audio)

- Unceasing customer service

Track the below URL for one-step submission https://juniperpublishers.com/online-submission.php 